\title{
Improving efficacy of landscape interventions in the (sub) humid Ethiopian highlands by improved understanding of runoff processes
}

\section{OPEN ACCESS}

Edited by:

David Glenn Chandler,

Syracuse University, USA

Reviewed by:

Tim Van Emmerik,

Delft University of Technology,

Netherlands

Scott Norman Wilkinson,

Commonwealth Scientific and Industrial Research Organisation,

Australia

*Correspondence:

Seifu A. Tilahun,

Faculty of Civil and Water Resources Engineering, Bahir Dar Institute of Technology, Bahir Dar University,

PO Box 26, Bahir Dar, Ethiopia sat86@cornell.edu

Specialty section:

This article was submitted to Hydrosphere, a section of the journal

Frontiers in Earth Science

Received: 16 January 2015

Accepted: 10 August 2015

Published: 02 September 2015

Citation:

Tebebu TY, Steenhuis TS, Dagnew $D C$, Guzman $C D$, Bayabil HK, Zegeye $A D$, Collick AS, Langan S, MacAlister

$C$, Langendoen EJ, Yitaferu $B$ and Tilahun SA (2015) Improving efficacy of landscape interventions in the (sub) humid Ethiopian highlands by improved understanding of runoff processes. Front. Earth Sci. 3:49. doi: 10.3389/feart.2015.00049
Tigist Y. Tebebu 1, Tammo S. Steenhuis ${ }^{1,2}$, Dessalegn C. Dagnew ${ }^{2}$, Christian D. Guzman ${ }^{1}$, Haimanote K. Bayabil ${ }^{1}$, Assefa D. Zegeye ${ }^{1,3}$, Amy S. Collick ${ }^{4}$, Simon Langan ${ }^{5}$, Charlotte MacAlister ${ }^{6}$, Eddy J. Langendoen ${ }^{7}$, Birru Yitaferu ${ }^{3}$ and Seifu A. Tilahun ${ }^{2 *}$

${ }^{1}$ Department of Biological and Environmental Engineering, Cornell University, Ithaca, NY, USA, ${ }^{2}$ Faculty of Civil and Water Resources Engineering, Bahir Dar Institute of Technology, Bahir Dar University, Bahir Dar, Ethiopia, ${ }^{3}$ Amhara Regional Agricultural Research Institute, Bahir Dar, Ethiopia, ${ }^{4}$ Pasture Systems and Watershed Management Research Unit, Department of Agriculture - Agricultural Research Service, University Park, PA, USA, ${ }^{5}$ International Water Management Institute Office for East Africa and Nile Basin, Addis Ababa, Ethiopia, ${ }^{6}$ International Development Research Centre, Ottawa, ON, Canada, ${ }^{7}$ Department of Agriculture - Agricultural Research Service, Watershed Physical Processes Research Unit, Oxford, MS, USA

Despite millions of dollars invested in soil and water conservation (SWC) practices in the (sub) humid Ethiopian highlands and billions of hours of food-for-work farm labor, sediment concentration in rivers is increasing. This paper reports on the research to reverse the current trend. Based on the understanding of the hydrology of highlands, we provide evidence on sources of surface runoff and sediment and on mechanisms that govern the erosion processes and approaches and how they affect SWC practices. We suggest that priority in landscape interventions should be given to re-vegetation of the degraded areas so as to reduce the sediment concentration contributions originating from these areas. Additionally, efforts should be directed to gully rehabilitation in the saturated bottom landscape that may consist of vegetating shallow gullies and stabilizing head cuts of deeper gullies. Finally, rehabilitation efforts should be directed to increase the rain water infiltration in the upland areas through the hardpan layer by connecting the land surface to the original deep flow paths that exist below about $60 \mathrm{~cm}$. It will reduce the direct runoff during the rainy season and increase baseflow during the dry season.

Keywords: monsoon climate, Africa, soil and water conservation practices, mountain hydrology, hardpan soil, landscape interventions

\section{Introduction}

Land degradation and associated soil erosion remain a persistent problem in the Ethiopian highlands, affecting both individual farmers, neighboring communities, and other water users in the landscape and in downstream areas. This land degradation is intimately linked to the expansion of agricultural practices into areas which were previously under forest land cover. During the last 50 years many efforts have been undertaken to conserve soil and water in the Ethiopian highlands, mainly with donor support, to reduce the pressure and impact of agriculture. In this effort the traditional off-contour furrows, were replaced by imported soil and water conservation (SWC) 
practices such as soil bunds, stone bunds and Fanya-Juu terraces, and enclosures (Mitiku et al., 2006). Most practices in the early 1970s and 1980s were installed with aid of the Food-For-Work natural resource conservation program administered by the Food and Agricultural Organization of the United Nations (Tamene and Vlek, 2008). In 2012 a government-led large scale watershed management program was launched as part of the ambitious Agricultural Growth and Transformation Plan (MOFED, 2010), which annually treats over 3000 community watersheds ( $>40,000$ hectares of land) with physical and biological SWC measures and involves more than 15 million people (MOA, 2013).

Despite all these conservation efforts, sediment concentrations continue to increase in rivers in the subhumid and humid (called humid for short) Ethiopian Blue Nile basin (Steenhuis and Tilahun, 2014). Clearly, past measures are not effective and, as Baveye (2013) put it, it is time to think boldly and thus for this case rethink the logic behind the transfer of SWC practices across regions with different climate and landscapes. In order to design effective landscape interventions, runoff and erosion processes in the landscape should be better understood. For example, the type of runoff process has a direct effect on placement of SWC practices. In watersheds, infiltration-excess runoff is generated on the hillsides and, as is currently the case, SWC practices are located on those hillsides. For saturation-excess runoff, water infiltrates on the hillsides and erosion-inducing runoff occurs in the flatter, downslope part of the landscape. SWC practices in this case would be more effective at the bottom of the slope.

To date, most studies on landscape interventions to control runoff and erosion processes in the Ethiopian highlands have been carried out in the semi-arid Tigray region situated in the northern part of Ethiopia (Nyssen et al., 2000, 2007, 2009; Gebremichael et al., 2005; Aerts et al., 2006; Descheemaeker et al., 2006a,b; Gebreegziabher et al., 2009; Girmay et al., 2009; Haregeweyn et al., 2013; and many others). Historically, much fewer comprehensive studies have been conducted in the humid highlands where landscape processes, soil types, and agroecological conditions are different. Soils in Tigray are generally coarser, covered by rock fragments, and have higher infiltration rates than those in the sub (humid) Blue Nile basin that are more clayey and much wetter. Therefore in the semi-arid northern parts, measures such as enclosures and stone bunds have been successful in increasing the water available for the crops growing in the bottom lands (Nyssen et al., 2009). Landscape intervention in the Machakos region in Kenya with just under $1000 \mathrm{~mm}$ annual rainfall in Kenya were also very successful (Tiffen et al., 1994). However, results of implementation of donor-supported SWC practices are mixed (at best) in the humid areas where rainfall exceeds potential evaporation and saturation excess (Herweg and Ludi, 1999; Bewket and Sterk, 2002; Mitiku et al., 2006; Dagnew et al., 2015).

The design of SWC practices for saturation excess in humid Ethiopian highlands has not been studied well. Consequently, our objective is to better understand the hydrological and erosion processes leading to saturation excess runoff in humid monsoon areas and based on this understanding design effective landscape management practices.

\section{Hypotheses and Theory}

Based on interdisciplinary research carried out over the last 6 years, the hydrological and sedimentary processes of the (sub) humid Blue Nile basin at different spatial and temporal scales of observation, we pose the following three-part hypotheses -

(1) Hydrological similarity of watersheds: Annual runoff and erosion patterns of the watersheds in the humid Ethiopian highlands are similar in space and time

(2) Saturation excess: Runoff and sediment originate from source areas saturated, either by a shallow regional groundwater in the valley bottom or from degraded areas with limited root zone storage for rainwater above a shallow restrictive layer

(3) Flow paths: Hillslopes with forests transmit infiltrated precipitation through the whole soil profile to the valley bottoms. After deforestation soils become degraded by forming restrictive layers at shallow depth forcing lateral flow to become shallower. This in turn reduces travel time, increases runoff and saturated land area, and reduces baseflow. Subsequently, to carry off the increase in wet season flow, effective drainage ways are created. These drainage ways are the gullies in the saturated lands.

The first part of the hypotheses on the similarity in time and space is important so we can devise principles for landscape interventions that are applicable to all of the (sub) humid Ethiopian highlands. The second part of the hypotheses indicates that effective landscape interventions should address the saturated source areas in the watershed, while the third part on flow paths explains why gullies are forming and how rehabilitation can be addressed.

\section{Materials and Methods}

Field studies to test the hypotheses were conducted in four watersheds in the Ethiopian highlands (Figure 1). Anjeni, Maybar, and Andit Tid are Soil Conservation Research Project (SCRP) watersheds, established in the 1980s to monitor soil erosion and efficiency of SWC measures such as graded FanyaJuus. The fourth watershed, Debre Mewi, was established by Amhara Regional Agricultural Research Institute (ARARI) in 2007 and we adopted it to carry out research on distributed runoff and erosion processes. Rainwater-dependent agriculture is the dominant land use type in all.

The 113 ha Anjeni watershed is oriented north-south and flanked on three sides by plateau ridges. It is located at $37^{\circ} 31^{\prime} \mathrm{E}$ and $10^{\circ} 40^{\prime} \mathrm{N}$ and lies $370 \mathrm{~km} \mathrm{NW}$ of Addis Ababa, to the south of the Choke Mountains (Figure 1B). Mean annual rainfall is $1690 \mathrm{~mm}$ and mean daily temperature ranges from 9 to $23^{\circ} \mathrm{C}$. In 1985 graded bunds, Fanya-Juu, were installed to terrace the hillslopes. Fanya-Juu ("throw uphill" in Swahili language) bunds are constructed by digging a trench and throwing the removed soil uphill to form a bund. In time, the space just above the bund has filled up with soil, having settled from ponded water or moved there by tillage, forming a terrace. Alisols, Nitisols, and Cambisols are the dominant soil types (Bayabil et al., 2015). 
A

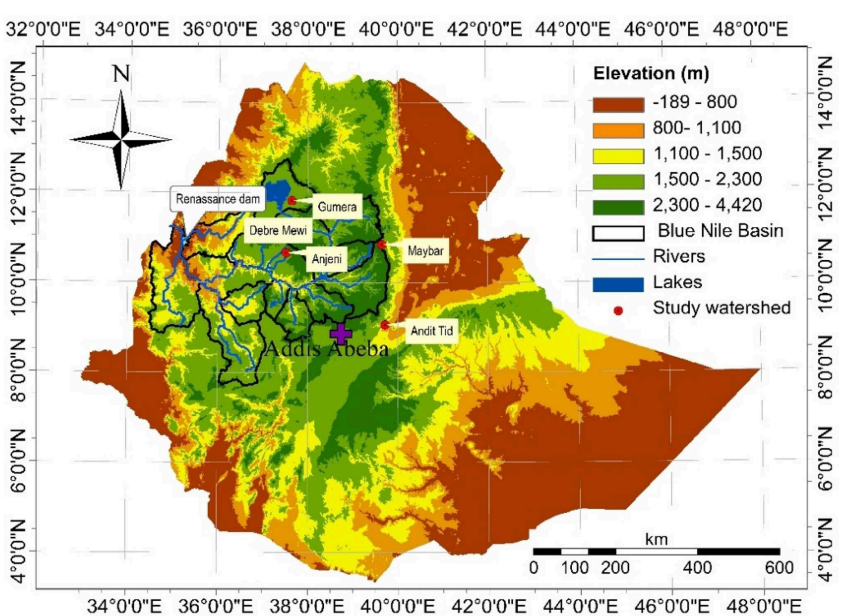

B

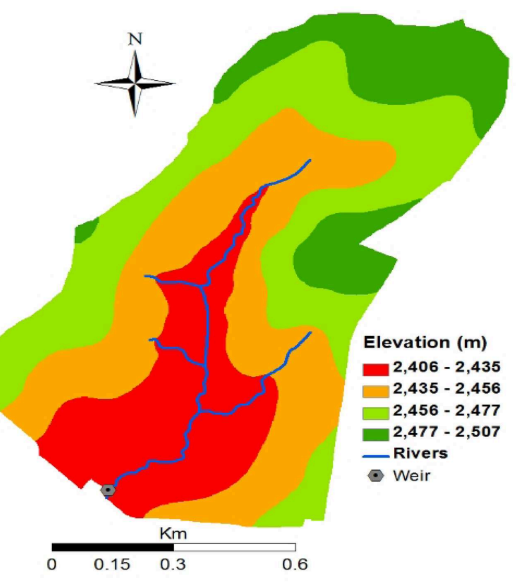

D

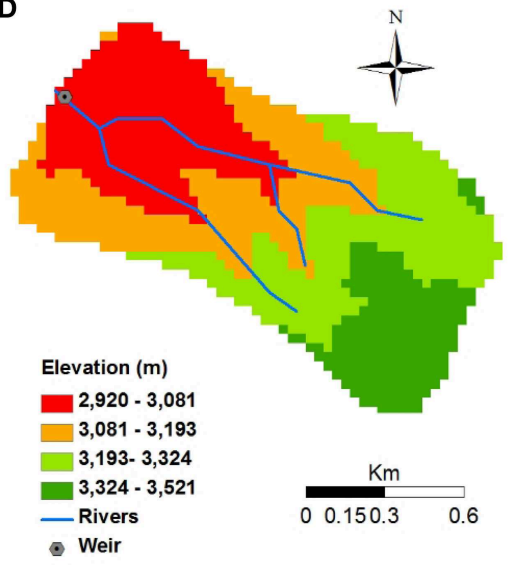

C

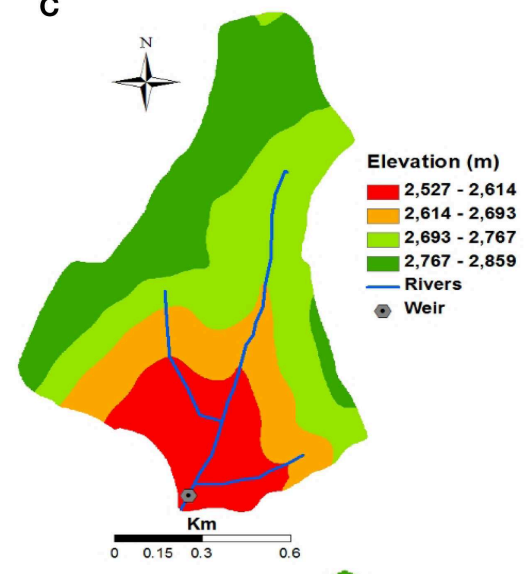

E

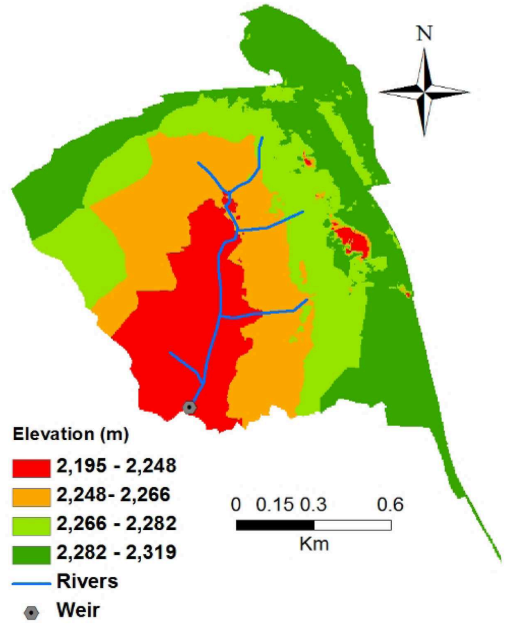

FIGURE 1 | The study watersheds in the Ethiopian highlands: (A) Map of Ethiopia, (B) Anjeni, (C) Maybar, (D) Andit Tid and (E) Debre Mewi.

More than 12 years data are available in which precipitation, discharge and storm event sediment yields were measured in the periods between 1984 and 1993 and 2012 and 2013 (Table 1).

The 113 ha Maybar watershed is located at $39^{\circ} 39^{\prime} \mathrm{E}$ and $10^{\circ} 51^{\prime} \mathrm{N}, 23 \mathrm{~km}$ to the southwest of Dessie in northeast Ethiopia (Figure 1C). Mean annual rainfall is $1210 \mathrm{~mm}$ and mean daily temperature ranges from 14 to $20^{\circ} \mathrm{C}$. The watershed drains into the Borkena River, which is a tributary of the Awash River. Phaeozems and Phaeozems associated to Lithosols are the dominant soil types, which are present in shallow layers (Bayabil, 2009; Yesuf et al., 2015). Precipitation, discharge and storm event sediment yields are available from 1988-1994, 1996-2004, and 2008 (Table 1). 
TABLE 1 | Summary of characteristics of study sites, annual precipitation, and observation periods.

\begin{tabular}{|c|c|c|c|c|c|}
\hline Watershed & $\begin{array}{l}\text { Watershed } \\
\text { area (ha) }\end{array}$ & Dominant soils types & $\begin{array}{l}\text { Mean annual } \\
\text { rainfall }(\mathrm{mm})\end{array}$ & Observation periods & Studies \\
\hline Anjeni & 113 & $\begin{array}{l}\text { Alisols, Nitisols, and } \\
\text { Cambisols }\end{array}$ & 1690 & 1984-1993 and 2012-2013 & $\begin{array}{l}\text { Liu et al., 2008; Guzman et al., 2013; Tilahun } \\
\text { et al., 2013a,b; Elkamil, 2014; Tebebu et al., } \\
\text { 2014; Bayabil et al., } 2015\end{array}$ \\
\hline Maybar & 113 & $\begin{array}{l}\text { Phaeozems and } \\
\text { Phaeozems associated to } \\
\text { Lithosols }\end{array}$ & 1210 & 1988-1994; 1996-2004 and 2008 & $\begin{array}{l}\text { Liu et al., 2008; Bayabil, 2009; Bayabil et al., } \\
\text { 2010; Guzman et al., } 2013\end{array}$ \\
\hline Andit Tid & 481 & Andosols and Regosols & 1500 & 1986-1992; 1994-2001 and 2008 & $\begin{array}{l}\text { Liu et al., 2008; Engda, 2009; Guzman et al., } \\
\text { 2013; Tilahun et al., 2013b }\end{array}$ \\
\hline Debre Mewi & 95 & Nitosols and Vertisols & 1240 & 2008-2014 & $\begin{array}{l}\text { Abiy, 2009; Tebebu, 2009; Tebebu et al., 2010; } \\
\text { Zegeye et al., 2010; Tilahun, 2012; } \\
\text { Langendoen et al., 2013; Dagnew et al., 2014; } \\
\text { Tebebu et al., 2014; Zegeye et al., 2014; } \\
\text { Dagnew et al., 2015; Tilahun et al., } 2015\end{array}$ \\
\hline
\end{tabular}

The Andit Tid watershed, situated $180 \mathrm{~km}$ northeast of Addis Ababa at $39^{\circ} 43^{\prime} \mathrm{E}$ and $9^{\circ} 48^{\prime} \mathrm{N}$, covers 481 ha (Figure 1D). On average, it receives $1500 \mathrm{~mm}$ rainfall annually and the mean daily temperature is $13^{\circ} \mathrm{C}$. Terraces and small contour drainage ditches were installed by farmers to transport excess rainfall of the field without causing excessive erosion. The watershed is characterized by shallow soil depth particularly at the lower part and Andosols and Regosols are the dominant soil types (Engda, 2009). Precipitation, discharge and storm event sediment yields are available from 1986 to 1992, 1994 to 2001, and 2008 (Table 1).

The Debre Mewi watershed is located $30 \mathrm{~km}$ south of Lake Tana, Bahir Dar, Ethiopia at $37^{\circ} 24^{\prime} \mathrm{E}$ and $11^{\circ} 20^{\prime} \mathrm{N}$ and covers 523 ha. Studies were conducted in a 95 ha sub watershed (Figure 1E). Mean annual rainfall is $1240 \mathrm{~mm}$ with a mean daily temperature of $24^{\circ} \mathrm{C}$. A SWC practices mainly furrows with soil bunds have been implemented over the past 3 years. Soils have developed from highly weathered and fractured basalt dominated by Nitosols and Vertisols soil types. Precipitation, discharge, and storm event sediment yields are available from 2008 to 2014 (Table 1). Additional experimental design details for all watersheds are given below.

\section{Results and Discussion}

The hypotheses is validated first and is followed by a discussion on effective management practices in a landscape with saturation excess runoff in a sub-humid and humid monsoon climate.

\section{Hypotheses Testing}

Based on the results of past studies, the validity of the threepart hypotheses is tested. We will first elaborate on the temporal and spatial similarity in runoff amounts and erosion patterns between different watersheds hundreds of kilometers apart. Next we will explain runoff mechanisms that are occurring in the landscape. Finally, we will report on the change of flow patterns in a landscape due to land degradation, and how these degraded areas are being formed and why they are increasing with time.
These degraded areas are defined according to their hydrological characteristics in that the downward flow through the restrictive layer is limited.

\section{Hydrological Similarity of Watersheds}

Available studies in the Ethiopian highlands with a humid monsoon climate found that despite the large differences in size, soil and geology, the discharge averaged over relatively short periods at the outlet of different watersheds behaves in a similar manner. The hydrological similarity over 14 day periods in watersheds can be seen by comparing the long-term discharge and sediment concentrations of the three SCRP watersheds (Figures 2, 3, 4), namely Andit Tid, Anjeni, and Maybar, located hundreds of kilometers apart. Liu et al. (2008) showed that for cumulative seasonal effective rainfall of $500 \mathrm{~mm}$ or more the proportion of rainfall that becomes runoff is remarkably the same. Figure 2 which is redrawn from Liu et al. (2008) shows that for all three watersheds, the discharge over a 14 day period as a function of the effective rainfall (defined as precipitation minus potential evaporation). The trend lines for each of the three exhibit a linear relationship of effective precipitation and amount of watershed outflow. The slope of the trend line is 0.5 for the Maybar and Anjeni watersheds (each approximately $100 \mathrm{ha}$ ). For the slightly larger Andit Tid watershed (i.e., 400 ha) the slope of the trend line is about 0.6 .

The linear relationship between discharge either from interflow or surface flow after a certain threshold in rainfall is exceeded is not uncommon as shown by Chandler and Walter (1998) for Leyte in the Philippines; and by Caballero et al. (2013) for Honduras, Czech Republic and by Wickel et al. (2008 for eastern Amazonia in Brazil). The linear relationship could also explain the closed lake level changes in Haiti and the Dominican Republic. Although the explanation of this linear relationship varies (e.g., Chandler and Walter, 1998), it seems that since rainfall intensity does not affect the relationship, direct runoff from a fixed source area with a shallow ground water table (either perched or regional) is the most likely explanation (Steenhuis 


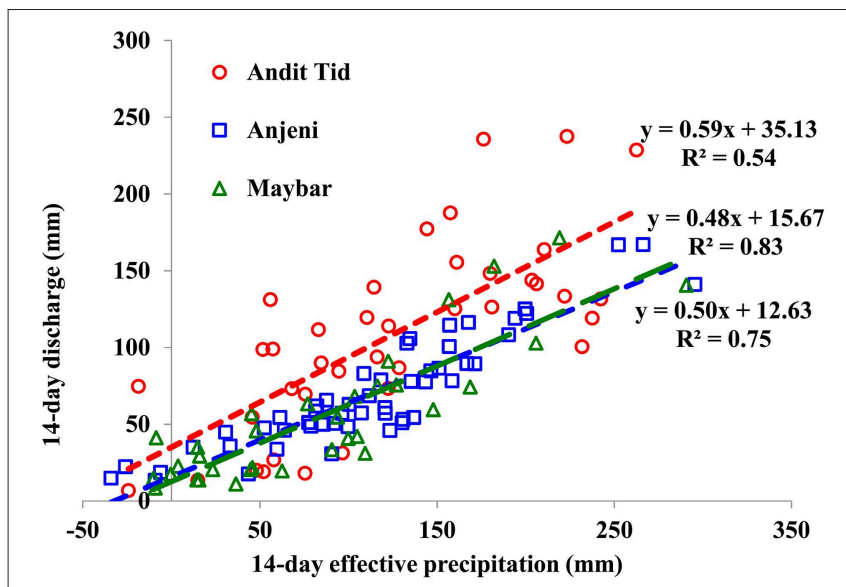

FIGURE 2 | Relationship between 14-day discharge and effective precipitation (precipitation minus potential evaporation) after $500 \mathrm{~mm}$. of cumulative effective precipitation occurring since the beginning of the rainy phase for three watersheds in the Ethiopian highlands (Liu et al., 2008). The dotted lines are the regression lines for each of the watersheds with the same colors as the symbols. The linear regression line in dot for each watershed is shown the latter/wetter rainy season.

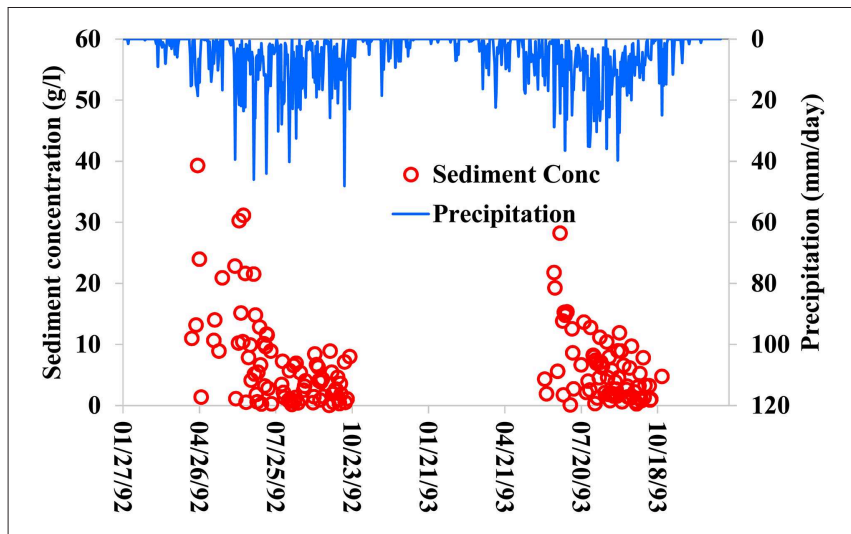

FIGURE 3 | Sediment concentration and rainfall for the Anjeni Watershed 6 years after installing terraces (Elkamil, 2014).

et al., 2013). For deep soils without restrictive layers, the source area is a relatively small part of the watershed (Caballero et al., 2013; Steenhuis et al., 2013). The opposite is true for watersheds with restrictive layers that have larger contributing areas and less baseflow.

As shown by Enku et al. (Forthcoming 2016) the Anjeni watershed reaches a point where approximately after 500$600 \mathrm{~mm}$ of cumulative effective rainfall the watershed is in equilibrium and no additional rain will be stored. The difference in rainfall and evaporation is the inflow that contributes to direct runoff (i.e., overland flow and interflow). Thus, the slope of the line is equal to the portion of the rainfall that contributes to direct runoff as shown in Figure 2. This portion of rainfall is approximately $50 \%$ for the just over 100 ha Anjeni and Maybar watersheds and nearly 60\% for the 400 ha Andit Tid watershed. Baseflow response after the rainstorm takes longer than 14 days,

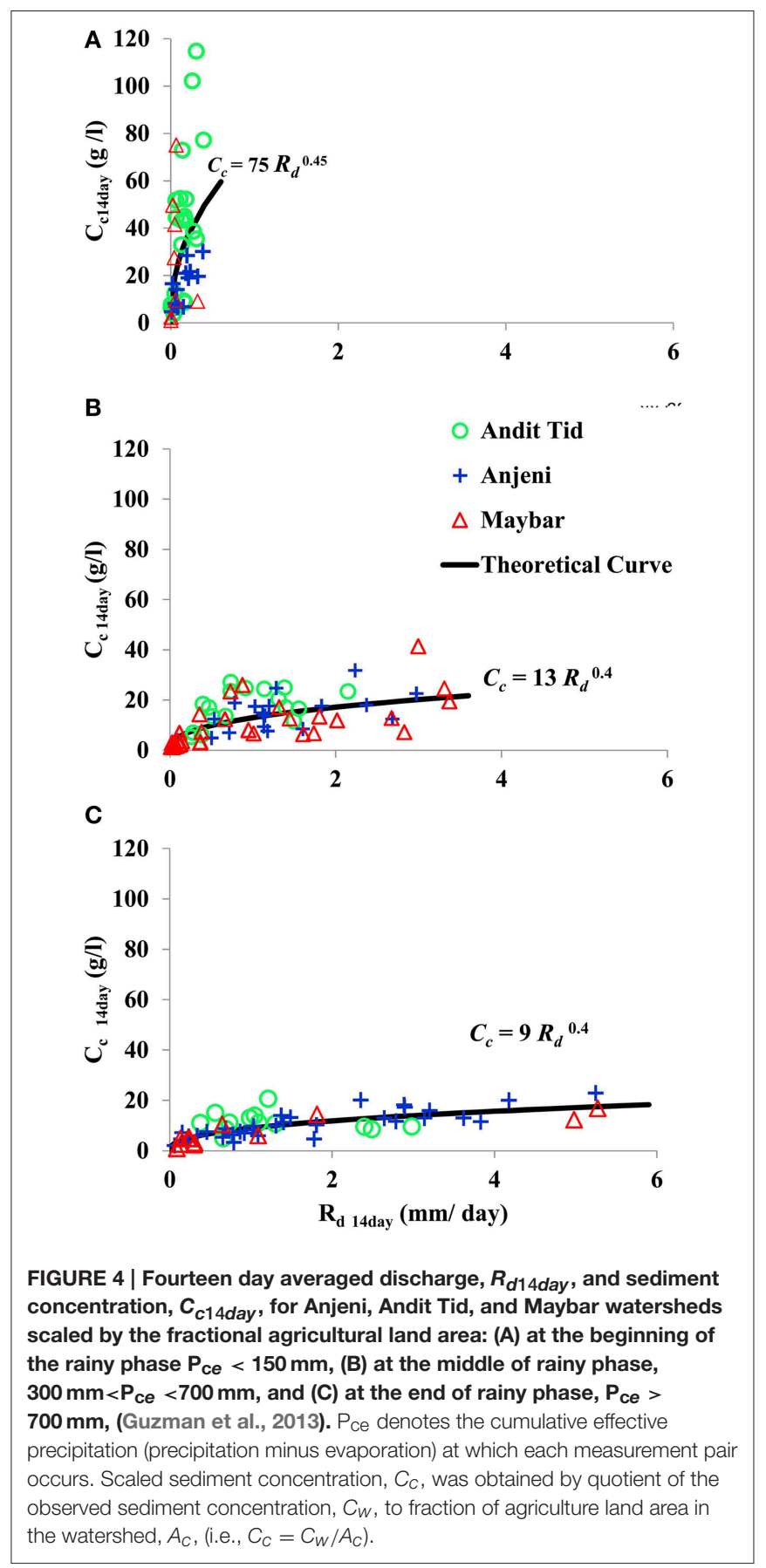

which is indicated by the positive intercept of runoff on the $\mathrm{Y}$ axis in the plot. Baseflow is approximately $1 \mathrm{~mm} /$ day for the Anjeni and Maybar watersheds (>500 km apart) and $2.5 \mathrm{~mm} /$ day for the wetter and larger Andit Tid Watershed.

As shown above and confirmed by modeling studies with a water balance (Engda et al., 2011; Tilahun et al., 2013a), the total annual outflow measured at the watershed outlet is less than total inflow (i.e., precipitation minus evaporation) into the watershed. Because these watersheds are located in the headwaters, some of the rainfall that infiltrates in the headwaters, 
either topographically drains toward the outlet becoming deep percolation (i.e., bed rock storage, Chandler, 2006) or appears as springs beyond the gage bypassing measurement and as base flow at the gage after the rainy monsoon phase ends.

Similar to the discharge behavior at the watershed outlet, temporal variation in sediment concentrations is comparable among the three watersheds. In all cases the sediment concentrations were much greater at the beginning than at the end of the rainy monsoon phase. An example was given for the Anjeni watershed by Elkamil (2014) showing elevated concentrations of sediment at the beginning of the rainy phase even 6 years after terraces were installed (Figure 3). This elevation was associated with freshly plowed, degraded soils in which rills are being formed by the excess rainfall that cannot infiltrate the hardpan at depth. Once the greatest intensity storms have passed in July, the rill network can carry the runoff from the remaining storms without the need to form additional rills. Consequently, the sediment concentrations decrease at the end of the rainy phase (Tilahun et al., 2013a,b; Steenhuis et al., 2014). Zegeye et al. (2010) and Tilahun et al. (2015) showed that rill formation stopped in August, and soil loss was greatly decreased from the uplands. The correlation of soil loss with plant cover was very weak (Tebebu et al., 2010) excluding plant cover as the cause for the decrease. Assuming that all sediment loss is originating from the agricultural areas the sediment concentrations can be scaled as the quotient of the observed concentration and the fraction of agricultural land in the watershed. The scaled concentration is plotted in Figure 4 as a function of the amount of cumulative precipitation since the beginning of the rainy phase. After scaling with the portion of agricultural land, the sediment concentration curves for the three SCRP watersheds coincide for each of the each of the intervals of cumulative precipitation (Figure 4, Guzman et al., 2013), indicating the great similarity in sediment transport between the watersheds.

\section{Saturation Excess}

The occurrence of saturation excess can be derived as discussed above from the linear relationship of total precipitation and direct storm runoff in Figure 2 for the three watersheds. In addition, comparison of infiltration rates with rainfall intensities allows us to determine the predominance of saturation or infiltration excess as well. Infiltration measurements in the Maybar (Derib, 2005; Bayabil et al., 2010), Anjeni (Bayabil et al., 2015), Debre Mewi (Tilahun, 2012), and Awramba watersheds (submitted) shows that the median of the infiltration rate is exceeded less than $10 \%$ of the time. Runoff under these conditions then occurs mainly when the soil is saturated near the surface by either a high regional or perched groundwater table on the degraded soils. In contrast to the degraded soils, undisturbed soils have a high lateral conductivity and drain quickly between rain events, especially for steep slopes, and very little overland flow occurs from these lands.

The previous discussion implies that the sources of sediment are the low gradient saturated zones and the degraded soils but not the well-drained hill slopes. This finding was confirmed by runoff plots at several slope positions in the Maybar watershed (Bayabil et al., 2010) where runoff coefficients were inversely proportional to the slope. Water table measurements in this watershed showed that water table depth and both slope and crop type were related. Grass was found on the periodically saturated bottom lands, cropped agricultural land on the mid-slopes with an intermediate (perched) water table and forest on the steep slopes where only during the rain storm and shortly thereafter a small perched water table could be measured. Similar findings were reported by Taye et al. (2013) in Tigray in the Ethiopian highlands in semi-arid monsoon climate agrees for experiments with large runoff plots. They found that the crop land had less runoff and erosion located on the relatively steeper hillsides than grass land on the land with less slope. Water table information was not available for this study and trampling of cattle could play a role for the greater runoff from the grassland.

The increase in degraded land has had a direct effect on the amount of runoff and sediment generated. We used the Parameter Efficient Distributed (PED) model to show that the degraded acreage in the watershed increased. In the PED model (for a description see Enku et al., 2014 and Tilahun et al., $2013 a, b)$, direct runoff is simulated as saturation excess runoff from both the periodically saturated bottom lands and the degraded lands using a simple water balance method by assuming that all excess rainfall above the threshold storage (i.e., air filled pore space) becomes direct runoff. Although this a solid assumption for the areas with the regional groundwater near the surface, it might be not as good for the degraded areas with a perched water table and where some downward infiltration could occur. Thus, the area of degraded land used in the model is the minimum area of degraded soils that has a perched water table and generates direct runoff. In the field the degraded area could be larger, however the quantity of direct runoff generated from it will remain unchanged since it is derived from the outflow hydrograph.

Sediment loss is simulated as a function of the predicted direct runoff from these two areas. Consequently in the model, an increase in degraded land runoff will result in a greater proportion of direct runoff and hence a greater sediment loss. It is thus possible to estimate the portion of additional runoff from the degraded areas in the watershed by fitting the discharge predicted by the PED model to the outflow signal. By fitting the discharge data of the Gumera River to the PED model, it was found that the direct runoff from the degraded area increased from 5 percent in the 1980s (1983-1992) to 13 percent in the 2000s (1995-2005) (Elkamil, 2014). Then by using the calibrated amount of direct runoff from the degraded areas of the 1980s (5\%) and of the 2000s (13\%), we predicted the sediment concentration in the runoff water with otherwise the same set of input parameters. In Figure 5, the predicted and observed sediment concentrations are shown. In the early time period (1983-1992) the 5 percent degraded area gives a good fit between observed and predicted sediment concentration while using the $13 \%$ degraded area over predicted the sediment concentrations. In the more recent period (1995-2005) the 13\% degraded area gives the best fit to the observed data (slope of the regression line close to 1) compared with the $5 \%$ degraded area that under predicted the sediment concentration. Similar analysis for the Blue Nile basin showed the same trends (Tesemma et al., 2010; Steenhuis and Tilahun, 

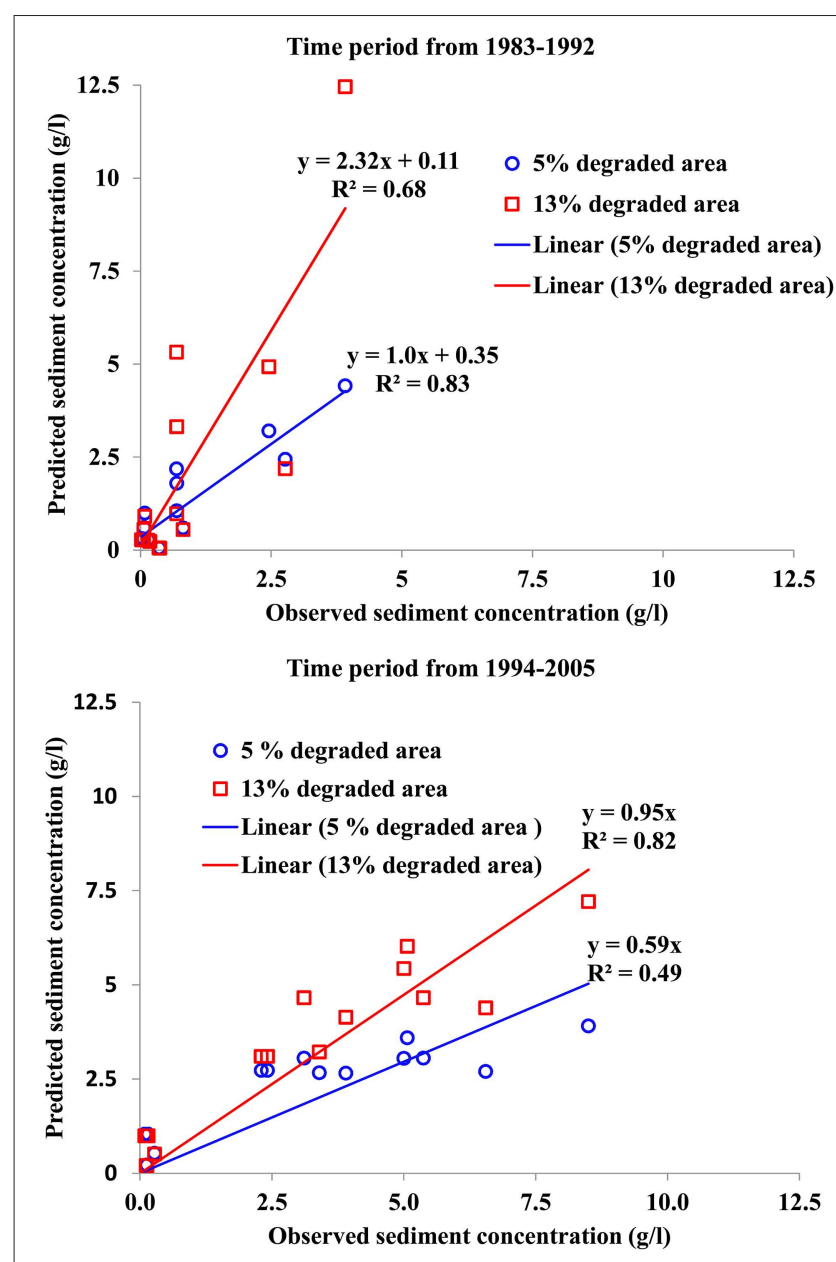

FIGURE 5 | Observed and predicted sediment concentration for the Gumera River in northwestern Ethiopia for the period of 1983-1992 (in top figure) and for the period of 1994-2005 (in the bottom figure). The red square markers (and red line) are for the 2000s when 13 percent of the watershed was degraded and the blue circles (and blue line) are for the 1980s when 5 percent of the watershed was degraded.

2014) where direct runoff and sediment increased and sediment concentration with time that could be related to an increase in the proportion of degraded areas. This is strengthening this type of analysis.

\section{Flow Path of Water}

In order to determine the change of flow patterns from a forest soil to a degraded soil, it is of interest to speculate how these degraded areas are being formed and why they are increasing with time. Tebebu et al. (2015) compared the penetration resistance of soils in agricultural fields (cultivated and pasture) and never-tilled forest lands surrounding Orthodox Christian churches (with a tradition of keeping a forest around the church and representing the original soil conditions) in Anjeni and Debre Mewi watersheds. In Debre Mewi watershed the mean percentage of clay and silt particles were $85 \%$ for the agriculture fields and $64 \%$ for forest lands. In the Anjeni watershed, it was 50,77 , and $74 \%$ in the forest, cultivated and grazing lands, respectively. Mean soil organic matter content in both watersheds was greater for the forest lands (approximately $7.2 \%)$ as compared to that of cultivated of $<2 \%$. Mean bulk density of cultivated lands was $1.38 \mathrm{~g} / \mathrm{cm}^{3}$ in Debre Mewi and $1.25 \mathrm{~g} / \mathrm{cm}^{3}$ in Anjeni watershed and for grazing lands $1.4 \mathrm{~g} / \mathrm{cm}^{3}$ in Debre Mewi and $1.2 \mathrm{~g} / \mathrm{cm}^{3}$ in Anjeni. These were much greater than in forest lands with a bulk density of $0.95 \mathrm{~g} / \mathrm{cm}^{3}$ on the average in both watersheds.

Tebebu et al. (2015) found hardpan soils in the agricultural fields starting at a depth of 15 to $30 \mathrm{~cm}$, see Figure 6. In the top $30 \mathrm{~cm}$ cattle on the wet grazing soils caused additional compaction (Figure 6). Sub soils in agricultural fields had such a high resistance $(>2000 \mathrm{kPa})$ that roots had difficulty penetrating them, while the church yards had much smaller or little resistance $(<1500 \mathrm{kPa})$. Similarly, Temesgen et al. $(2009,2012)$ found dense subsoil in the agricultural fields of the Enerta watershed, a few kilometers away from Anjeni watershed. Soil penetration resistance of approximately $2000 \mathrm{kPa}$ was found to be a critical threshold value that can limit root capacity to penetrate and restrict soil water movement (Hamza and Anderson, 2005). Figure 7 shows a typical degraded soil profile. The original soil structure with large vertical pores is seen below $60 \mathrm{~cm}$, while from 0 to $60 \mathrm{~cm}$ the soil is a solid mass with the original cracks filled up with soil. These large pores were established by the roots of the woody vegetation and are fundamental through which the rapid infiltration of water can occur.

Decrease in organic matter can explain the greater silt and clay content of the cropped and pasture fields compared to the forest. Fine particles are bound together by the organic matter in stable aggregates. Once the organic matter decreases the aggregates disintegrate. The resulting fine particles are easily suspended in the runoff water, we found up to $4 \%$ solids in the discharge waters. The sediment laden water infiltrates into the soil and plugs up the large macropores adding additional silt and clay to the profile in addition to the fine particles from the disintegrated aggregates.

The hardpan formation has a direct consequence on the resulting peak flow immediately after the occurrence of a storm event, because of a major modification in the length of the flow path of the subsurface flow. Before the soil became degraded, the water infiltrated and followed a long and deep flow path to the stream to become baseflow long after the rain had stopped. However, with the formation of a hardpan these longer paths are blocked and a much more shallow and direct flow occurs as interflow to the lowlands. Anecdotal evidence of this process is given by the farmers in the Fogera Plain who reported that in early times a rainstorm in the headwater of the Gumera would produce elevated stream levels the following day, but presently the flood comes shortly after the rainfall. The change in flow paths requires the landscape to adjust to these increased direct flows by forming effective pathways to carry this water to the stream. These pathways are the gullies that have appeared all over the landscape a few years after the uplands were cleared and became more intensively used in the middle of the 14 year period of the communist regime from 1977 to 1991 in which the fertile bottom lands were taken over by the regime (Tebebu et al., 2010; Ayele et al., in press). 


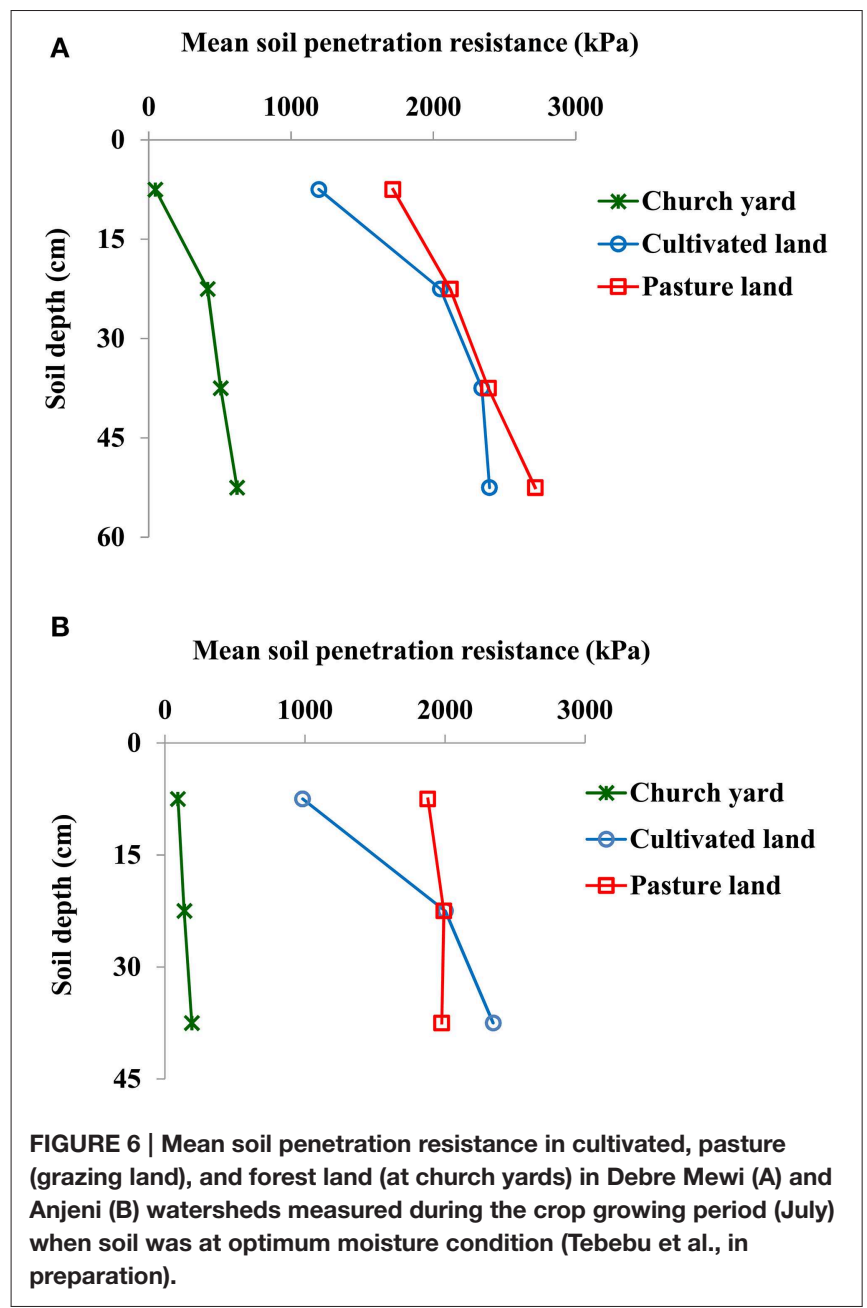

\section{Effective Landscape Interventions Practices}

As mentioned in the introduction, despite millions of dollars invested on SWC practices (Osman and Sauerborn, 2001), sediment concentrations have continuously increased in the rivers of the Ethiopian Highlands. The main reason for the increase is that traditional donor-sponsored landscape interventions are being installed on hillslopes irrespective of the hydrology. Mitiku et al. (2006) and Dagnew et al. (2015) showed that poorly placed SWC practices concentrate runoff and will increase soil loss. In contrast, effective landscape interventions will decrease soil loss from source areas where the sediment is generated. For the sub humid and humid Ethiopian highlands these source areas are the degraded lands and the periodically saturated bottom lands. We will discuss appropriate landscape interventions for the two areas below.

\section{Landscape Interventions for Degraded Soils that have Formed a Hardpan at Shallow Depth}

Degraded soils are caused in part by clogging of the original macropores that decrease infiltration and increase runoff and erosion from these lands. These degraded areas can take various forms. The most severely degraded areas are bare because the

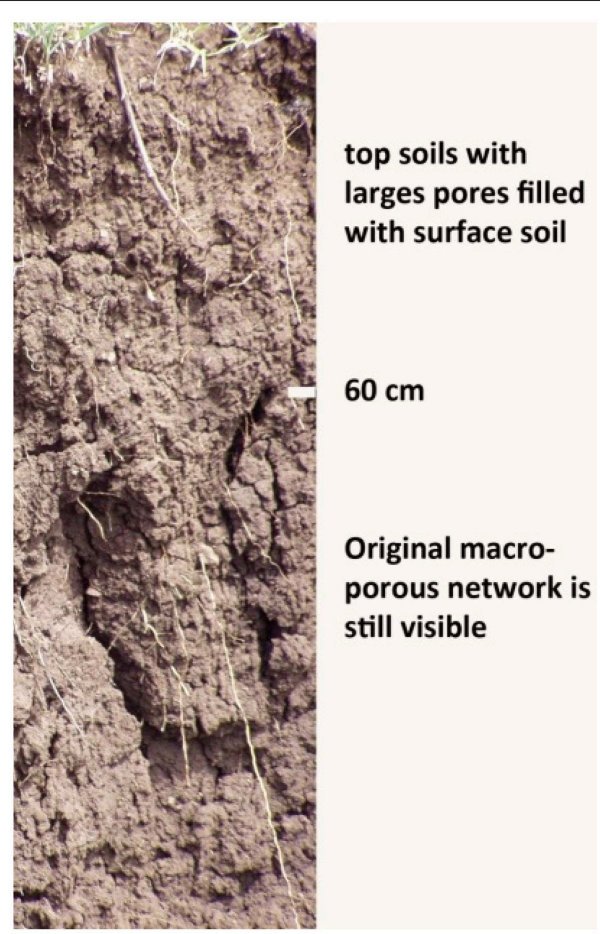

FIGURE 7 | A degraded soil profile: the original flow paths are only present in the lower part of the profile (below $60 \mathrm{~cm}$ ).

subsoil does not support any crop and likely have the greatest soil losses (exceeded only by the gullies). Agricultural fields can be degraded as well. At the beginning of the rainy monsoon phase these plowed fields become potential sources for elevated sediment concentration.

In order to rehabilitate these soils the infiltration rate through the hardpan should be increased. Digging $50 \mathrm{~cm}$ deep furrows through the dense layer as part of the recent government sponsored large-scale conservation implementation program, increased infiltration and reduced runoff on soils in which the water table remained below the surface. In contrast, furrows installed in areas that saturated during the rainy phase of the monsoon have already formed gullies 2 years after installation, because they concentrate all the diffuse overland and subsurface flow to a common point (Dagnew et al., 2015). The most effective SWC practices are those that increase the infiltration rate of the hardpan and connect the surface with the existing macropore network below $60 \mathrm{~cm}$ such that water can flow via the deep flow paths to the outlet. Investigations on the Anjeni plots have demonstrated that maintenance is required for this practice to remain effective. Observations at the Debre Mewi watershed (Dagnew et al., 2015) support this recommendation since in just 2 years after installation most of the established furrows are already half-filled with deposited sediment.

In the case of a hardpan, a suggested promising method that will not put any land out of production is to rip through the hardpan along the contour at intervals of several meters, and by filling the ripped areas with straw or other organic matter 
to form high conductive paths to the subsurface (Table 2) such as proposed by Saxton et al. (1981) and have shown to increase infiltration into frozen soils significantly (Schillinger and Wilkins, 1997; Pikul and Aase, 1998). Williams et al. (2006) found that rotary sub-soiling decreases runoff as well. In Ethiopia as well, sub soiling of cultivated lands by ripping the compacted soil significantly reduced surface runoff and sediment production (Temesgen et al., 2012). At the same time, the sediment content of the water could be reduced by increasing the $\mathrm{pH}$ of the soil through application of lime. Reduction of the sediment concentration in the infiltrating water reduces the possibility of hardpan formation. However, additional research is needed to validate these recommendations. Adding straw may also be good for enhanced denitrification processes in the areas where nitrogen is a problem.

Another method to reduce erosion without infiltration furrows or mechanically breaking up the hardpan is to replant the severely degraded areas with fruit trees or elephant grass (Table 2). The roots penetrate the hardpan and form a transport path of the water and at the same time will reduce the concentration of sediment in the infiltration water preventing clogging of the pores (Ziegler and Giambelluca, 1998). Good examples of conversion of degraded land to forest or orchards can be seen along the road connecting Bahir Dar to Gondar. The aid the establishment of reforested lands, they can be irrigated from groundwater during the dry season which is important for the young fruit trees to survive. Once established leaf fall and root turnover will add to organic matter and soil carbon which both retains soil moisture and changes soil texture and $\mathrm{pH}$.

No till has proven to reduce erosion. In the studied Debre Mewi plots soil loss only started after the fields were plowed. However, the difficulty with no till is that it will require pesticides to combat the weeds and insects that may cause crop failure (McHugh et al., 2007). In addition, the vegetation or crop residue that is expected to serve as protective cover or organic material is typically used as animal feed in these smallholder agricultural systems.

\section{Landscape Interventions for Periodically Saturated Source Areas on Less Sloping Lands near Watercourses}

The saturated areas of agricultural hillslopes are usually located near watercourses or above barriers where interflow resurfaces. This, for example is observed in the Debre Mewi watershed where lava intrusion dikes are one of these barriers above which a saturated area is formed (Abiy, 2009). These saturated areas are not a source of sediment when fully covered with wetland plants. However, once cultivated, and especially when overgrazed, these lands become sediment source areas.

In many cases the saturated areas are also the location where gullies form (Tebebu et al., 2010). Once initiated these gullies expand rapidly, especially at locations where water tables are above the gully bottom. In saturated soil, the strength is reduced. Because of both the absence of bedrock and the minimal soil strength, these gullies can deeply incise into the terrain. In Figure 8 shows one of the many rapidly advancing gullies in the Debre Mewi watershed. Banks collapse easily due to high ground water table and become a large source of sediment that is easily being picked up by the water flowing through the gully from upper part of the watershed. Zegeye et al. (2014) measured that up to $95 \%$ of the sediment is contributed by these gullies. As a result, any sediment captured upslope in the watershed does not translate into a reduction in sediment concentration measured downstream. This is confirmed by the study in Debre Mewi of Dagnew et al. (2015) finding that average concentrations downstream of the expanding gullies slightly increase after installation of furrows with bunds to control soil erosion. However, the overall soil loss (at least on the short

TABLE 2 | Summary of recommended landscape interventions.

\begin{tabular}{|c|c|c|}
\hline Landscape intervention & Purpose & Location of application \\
\hline \multirow[t]{2}{*}{$\begin{array}{l}\text { Ripping the hardpan with filling the ripped } \\
\text { areas with straw or other organic matter }\end{array}$} & $\begin{array}{l}\text { Connect the surface with the existing macropore network } \\
\text { Increase infiltration rate of the hardpan and reduce runoff and sediment } \\
\text { production }\end{array}$ & $\begin{array}{l}\text { Degraded soils with a hardpan at } \\
\text { shallow depth mostly in the } \\
\text { agricultural hillslopes }\end{array}$ \\
\hline & Enhance denitrification processes in nitrogen deficient areas & \\
\hline Lime application & Increase pH & \\
\hline $\begin{array}{l}\text { Deep furrows with continuous } \\
\text { maintenance }\end{array}$ & Connect the surface with the existing macropore network & \\
\hline \multirow[t]{3}{*}{$\begin{array}{l}\text { Re-vegetation with fruit trees or elephant } \\
\text { grass }\end{array}$} & Roots penetrate the hardpan and form a transport path of the water & $\begin{array}{l}\text { Saturated source areas on less } \\
\text { sloping lands }\end{array}$ \\
\hline & $\begin{array}{l}\text { Reduce the concentration of sediment in the infiltration water and } \\
\text { preventing clogging up of the pores }\end{array}$ & Actively incising gully channels \\
\hline & $\begin{array}{l}\text { Add organic matter and soil carbon which both retains soil moisture } \\
\text { and changes soil texture and } \mathrm{pH}\end{array}$ & $\begin{array}{l}\text { Lands with a hardpan soil at shallow } \\
\text { depth }\end{array}$ \\
\hline $\begin{array}{l}\text { Stabilizing gully head cuts from } \\
\text { downstream to upstream }\end{array}$ & Stabilize upslope migrating gully head cuts & $\begin{array}{l}\text { Actively incising gully channels in the } \\
\text { less sloping saturated areas }\end{array}$ \\
\hline
\end{tabular}




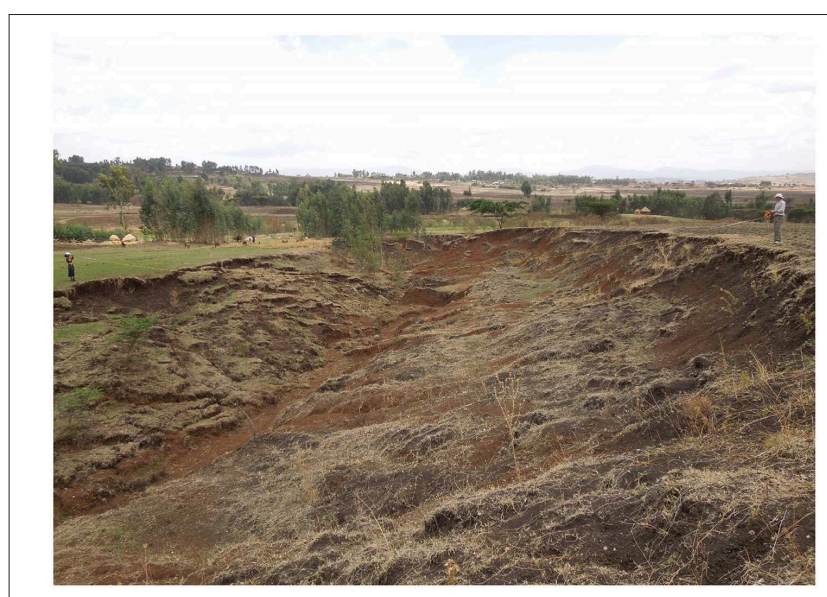

FIGURE 8 | Gully in the Debre Mewi watershed.

term) decreased because more rainwater infiltrated and runoff was reduced.

Therefore, effective ways to control gully erosion need to be developed. This is not an easy task, and research should be carried out to develop best management practices at the smallest possible cost to farmers. However, incising channels such as gullies experience a predictable, non-reversible series of adjustment processes (Schumm et al., 1984). Upslope migrating head cuts increase gully depth and slope, destabilizing the gully banks, resulting in widening, and downstream deposition (Tebebu, 2009; Tebebu et al., 2010; Langendoen et al., 2013). Hence, it is important to note that gully stabilization should proceed from downstream to upstream by halting the headward migration of head cuts (Table 2), which will otherwise severely damage any improvement made on the hillslopes and headwaters.

\section{Conclusions and Recommendations}

Combatting the growing sediment loads in the Ethiopian highlands requires understanding the roots of land degradation. This paper is intended to serve as a contribution to the discourse both on the interaction between hydrology, land degradation, and sediment concentrations as well as on the types of landscape interventions that can be implemented to reverse the current trend of unsustainable land use in the (sub) humid monsoonal climate.

To determine the interaction in the degrading landscape with hydrology and sediment concentrations we validated three hypotheses with discharge, sediment, and rainfall data of four watershed in the humid Ethiopian highlands at more than 500 $\mathrm{km}$ apart. We found that:

After the watersheds wet up, a hydrological similarity exists in sub humid and humid watersheds that consist of: a linear relationship between rainfall and direct discharge over 14 day periods. Part of direct discharge is interflow that is transmitted rapidly down the moderate to steep slopes. The remainder is saturation excess runoff from the periodically saturated bottom lands or a perched water table on the degraded hillsides. Sediment concentrations in discharge are always much greater for a given amount of runoff in the beginning of the rainy phase than at then at the end. The concentrations at given time between watersheds vary with the proportion of cultivated agricultural area in the watershed. Thus, the general hydrological principles of landscape interventions from one watershed can be transferred to other watersheds in the (sub) humid Ethiopian highlands.

Soil degradation leads to accelerated formation of a near surface restrictive layer and restricts infiltration to the subsoil. As a result lateral flow paths have become shallower reducing travel time to the outlet, increasing runoff, reducing base flow, and a greater regional water table depth saturating more of the valley bottom. To accommodate the increased rate of shallow lateral flow, more effective lateral drainage ways are created. These drainage ways are the gullies in the saturated areas.

Saturation excess runoff is common and originates spatially both from areas in which the regional groundwater reaches the surface at the lower slope positions and from the degraded areas with perched water table over the restrictive layer. The effective drainage ways become gullies in the saturated areas with little soil strength and drain the increased flow from the hillsides during the rainy phase as a consequence of the soil degradation. The newly formed gullies are the greatest sources of sediment in the watershed outflow.

Based on these validated hypotheses, we advocate a set of conservation practices that are intended to increase the infiltration rate for the degraded areas on the hillsides and to protect the saturated and severely eroded areas with vegetation so that they can facilitate overland flow without picking up sediment. In many ways these SWC practices are different in the wet climates where rainfall exceeds the evaporation during the rainy monsoon phase from those applied in dryer areas. For humid areas, drainage of excess rain water takes priority over water conservation in the root zone. Management practices developed in semi-arid monsoon climates such as in Tigray or Machakos area in Kenya should be carefully adapted before recommending for wetter climates.

In addition, we have stressed the importance of controlling gully erosion starting at the outlet. The latter suggests that engineers in planning watershed interventions should consider the whole watershed and not start SWC practices by default at the top of the watershed. This work needs some further testing to refine limits to applicability and to generate wider evidence base. The benefits from which are not just the farmers and agricultural communities in the immediate landscape but also for water users, communities and industries downstream; nowhere is this more important than the rapidly developing Blue/Eastern Nile region.

\section{Author Contributions}

This paper is the end results of research and deliberations of a group of faculty, researchers, and graduate students working in the Blue Nile Basin in Ethiopia. TS, AC, CM, BY, and ST 
conceived and designed the experiments. TT, DD, CG, HB, and AZ performed the experiments. TT, HB, AZ, DD, ST, TS, and CG analyzed the data. EL contributed materials and analysis tools. TT, TS, CG, and ST led the development of this manuscript.

\section{Acknowledgments}

The data for this paper were collected with funding from several sources including the International Foundation for Science (IFS), Higher Education for Development (HED),

\section{References}

Abiy, A. Z. (2009). Geological Controls in the Formations and Expansions of Gullies over Hillslope Hydrological Processes in the Highlands of Ethiopia, Northern Blue Nile Region. Master's thesis. Cornell University, Ithaca, NY.

Aerts, R., Maes, W., November, E., Behailu, M., Poesen, J., Deckers, J., et al. (2006). Surface runoff and seed trapping efficiency of shrubs in a regenerating semi-arid woodland in northern Ethiopia. Catena 65, 61-70. doi: 10.1016/j.catena.2005.09.004

Ayele, G. K., Gessess, A. A., Addisie, M. B., Tilahun, S. A., Tebebu, T. Y., Tenessa, D. B., et al. (in press). A biophysical and economic assessment of a communitybased rehabilitated gully in the Ethiopian highlands. Land Degrad. Dev. doi: $10.1002 / \mathrm{ldr} .2425$

Baveye, P. C. (2013). Hydrology and the looming water crisis: it is time to think, and act, outside the box. J. Hydrol. Hydromech. 61, 89-96. doi: 10.2478/johh2013-0012

Bayabil, H. K. (2009). Modeling Rainfall-runoff Relationship and Assessing Impacts of Soil Conservation Research Program Intervention on Soil Physical and Chemical Properties at Maybar Research Unit, Wollo, Ethiopia. Master's thesis. Cornell University, Ithaca, NY.

Bayabil, H. K., Stoof, C. R., Lehmann, J. C., Yitaferu, B., and Steenhuis, T. S. (2015). Assessing the potential of biochar and charcoal to improve soil hydraulic properties in the humid Ethiopian Highlands: the Anjeni watershed. Geoderma 243, 115-123. doi: 10.1016/j.geoderma.2014. 12.015

Bayabil, H. K., Tilahun, S. A., Collick, A. S., Yitaferu, B., and Steenhuis, T. S. (2010). Are runoff processes ecologically or topographically driven in the (sub) humid Ethiopian highlands? The case of the Maybar watershed. Ecohydrology 3, 457-466. doi: 10.1002/eco.170

Bewket, W., and Sterk, G. (2002). Farmers' participation in soil and water conservation activities in the Chemoga watershed, Blue Nile basin, Ethiopia. Land Degrad. Dev. 13, 189-200. doi: 10.1002/ldr.492

Caballero, L. A., Easton, Z. M., Richards, B. K., and Steenhuis, T. S. (2013). Evaluating the bio-hydrological impact of a cloud forest in Central America using a semi-distributed water balance model. J. Hydrol. Hydromech. 61, 9-20. doi: 10.2478/jhh-2013-0003

Chandler, D. G. (2006). Reversibility of forest conversion impacts on water budgets in tropical karst terrain. Forest Ecol. Manage. 224, 95-103. doi: 10.1016/j.foreco.2005.12.010

Chandler, D. G., and Walter, M. F. (1998). Runoff responses among common land uses in the uplands of Matalom, Leyte, Philippines. Trans. ASAE 41, 1635-1641. doi: $10.13031 / 2013.17338$

Dagnew, C. D., Guzman, C. D., Zegeye, A. D., Tibebu, T. Y., Getaneh, M., Abate, S., et al. (2015). Impact of conservation practices on runoff and soil loss in the subhumid Ethiopian Highlands: the Debre Mawi watershed. J. Hydrol. Hydromech. 63, 210-219. doi: 10.1515/johh-2015-0021

Dagnew, C. D., Tilahun, S. A., Guzman, C. D., Ayana, E. K., Zegeye, A. D., Tebebu, T. Y., et al. (2014). "Hydrologic and Sediment response to the large scale soil and water conservation implementation in a sub-humid watershed in the Ethiopian highlands," in 2nd International Conference on the Advancements of Science and Technology, Bahir Dar Institute of Technology, eds B. Bantyirga, M. Mehari, V. S. Rao, B. L. Manocha, K. K. Singh, S.
USDA International Science and Education (ISE) program, National Science Foundation (NSF) through Cornell's Food Systems and Poverty Reduction Integrative Graduate Education and Research Traineeship (IGERT) program and Graduate Research Fellowship program, Borlaug Leadership Enhancement in Agriculture Program (LEAP), First Presbyterian Church of Ithaca and the Blue Nile Water Institute. In addition, we are grateful for the PEER Science Program of USAID and CGIAR Research program on Water, Land and Ecosystem (a part of the Nile and East Africa Focal Region).

Geremew and E. Tadesse (Bahir Dar: Bahir Dar Institute of Technology), $130-142$.

Derib, S. D. (2005). Rainfall Runoff Processes at a Hill Slope Watershed: Case of Simple Models Evaluation at Kori Sheleko Catchment of Wollo, Ethiopia. Hydrology and Quantitative Water Management Group. MSc thesis. Wageningen University, Wageningen.

Descheemaeker, K., Nyssen, J., Poesen, J., Raes, D., Haile, M., Muys, B., et al. (2006b). Runoff on slopes with restoring vegetation: a case study from the Tigray highlands, Ethiopia. J. Hydrol. 331, 219-241. doi: 10.1016/j.jhydrol.2006.05.015

Descheemaeker, K., Nyssen, J., Rossi, J., Poesen, J., Haile, M., Raes, D. B., et al. (2006a). Sediment deposition and pedogenesis in exclosures in the Tigray Highlands, Ethiopia. Geoderma 132, 291-314. doi: 10.1016/j.geoderma.2005.04.027

Elkamil, M. I. (2014). Trends in River Discharge, and Sediment Concentrations in the (semi) Humid Watersheds of the Blue Nile in Ethiopia. Master's thesis, Cornell University, Ithaca, NY.

Engda, T. A. (2009). Modeling Rainfall, Runoff and Soil Loss Relationships in the Northeastern Highlands of Ethiopia, Andit Tid watershed. Master's thesis. Cornell University, Ithaca, NY.

Engda, T. A., Bayabil, H. K., Legesse, E. S., Ayana, E. K., Tilahun, S. A., Collick, A. S., et al. (2011). "Watershed hydrology of the (Semi) humid ethiopian highlands," in Nile River Basin: Hydrology, Climate and Water Use, ed A. M. Melesse (Springer), 145-162.

Enku, T., Melesse, A. M., Ayana, E. K., Tilahun, S. A., Zeleke, G., and Steenhuis, T. S. (Forthcoming 2016). "Watershed storage dynamics in the Upper Blue Nile Basin: the Anjeni experimental watershed, Ethiopia," in Landscape Dynamics, Soil and Hydrological Processes in Varied Climates, Vol. 3, eds A. M. Melesse, W. Abtew (Switzerland: Springer International Publishing), 261-277.

Enku, T., Taddesse, A., Lijalem, D., Alebachew, A., Belachew, M., Abate, M., et al. (2014). Biohydrology of low flows in the humid Ethiopian highlands: the Gilgel Abay catchment. Biologia 69, 1502-1509. doi: 10.2478/s11756-0140462-9

Gebreegziabher, T., Nyssen, J., Govaerts, B., Getnet, F., Behailu, M., Haile, M., et al. (2009). Contour furrows for in situ soil and water conservation, Tigray, Northern Ethiopia. Soil Tillage Res. 103, 257-264. doi: 10.1016/j.still.2008.05.021

Gebremichael, D., Nyssen, J., Poesen, J., Deckers, J., Haile, M., Govers, G., et al. (2005). Effectiveness of stone bunds in controlling soil erosion on cropland in the Tigray highlands, Northern Ethiopia. Soil Use Manage. 21, 287-297. doi: 10.1079/SUM2005321

Girmay, G., Singh, B., Nyssen, J., and Borrosen, T. (2009). Runoff and sedimentassociated nutrient losses under different land uses in Tigray, Northern Ethiopia. J. Hydrol. 376, 70-80. doi: 10.1016/j.jhydrol.2009.07.066

Guzman, C., Tilahun, S., Zegeye, A., and Steenhuis, T. (2013). Suspended sediment concentration-discharge relationships in the (sub-) humid Ethiopian highlands. Hydrol. Earth Syst. Sci. 17, 1067-1077. doi: 10.5194/hess-17-10 67-2013

Hamza, M., and Anderson, W. (2005). Soil compaction in cropping systems: a review of the nature, causes and possible solutions. Soil Tillage Res. 82, 121-145. doi: 10.1016/j.still.2004.08.009 
Haregeweyn, N., Poesen, J., Verstraeten, G., Govers, G., Vente, J., Nyssen, J., et al. (2013). Assessing the performance of a spatially distributed soil erosion and sediment delivery model (WATEM/SEDEM) in northern Ethiopia. Land Degrad. Dev. 24, 188-204. doi: 10.1002/ldr.1121

Herweg, K., and Ludi, E. (1999). The performance of selected soil and water conservation measures-case studies from Ethiopia and Eritrea. Catena 36, 99-114. doi: 10.1016/S0341-8162(99)00004-1

Langendoen, E. J., Tebebu, T. Y., Steenhuis, T. S., and Tilahun, S. A. (2013). "Assessing Gully Widening and its control in the Debre-Mawi Watershed, northern Ethiopia," in Proceedings Conference on Science and Technology Towards the Development of East Africa (ICST 2013), eds N. Gabbiye, E. Kaba, K. K. Monocha Singh, and S. Sharma (Bahir Dar University Institute of Technology: Ethiopia), 214-222.

Liu, B. M., Collick, A. S., Zeleke, G., Adgo, E., Easton, Z. M., and Steenhuis, T. S. (2008). Rainfall-discharge relationships for a monsoonal climate in the Ethiopian highlands. Hydrol. Process. 22, 1059-1067. doi: 10.1002/ hyp.7022

McHugh, O. V., Steenhuis, T. S., Abebe, B., and Fernandes, E. C. (2007). Performance of in situ rainwater conservation tillage techniques on dry spell mitigation and erosion control in the drought-prone North Wello zone of the Ethiopian highlands. Soil Tillage Res. 97, 19-36. doi: 10.1016/j.still.2007. 08.002

Mitiku, H., Herweg, K., and Stillhardt, B. (2006). Sustainable Land ManagementA New Approach to Soil and Water Conservation in Ethiopia. Technical report, Land Resource Management and Environmental Protection Department, Mekelle University, Mekelle, Ethiopia, Center for Development and Environment (CDE), University of Bern and Swiss National Center of Competence in Research (NCCR) North-South, Bern.

MOA. (2013). Annual Report of the Ministry of Agriculture for 2013/2014. Addis Ababa.

MOFED. (2010). Growth and Transformation Plan of Ethiopia (GTP), 2010/20112014/15 of the Federal Democratic Republic of Ethiopia (FDRE). Addis Ababa.

Nyssen, J., Clymans, W., Poesen, J., Vandecasteele, I., De Baets, S., Haregeweyn, N., et al. (2009). How soil conservation affects the catchment sediment budgeta comprehensive study in the north Ethiopian highlands. Earth Surface Process. Landforms 34, 1216-1233. doi: 10.1002/esp.1805

Nyssen, J., Poesen, J., Gebremichael, D., Vancampenhout, K., D’aes, M., Yihdego, G., et al. (2007). Interdisciplinary on-site evaluation of stone bunds to control soil erosion on cropland in Northern Ethiopia. Soil Tillage Res. 94, 151-163. doi: 10.1016/j.still.2006.07.011

Nyssen, J., Poesen, J., Haile, M., Moeyersons, J., and Deckers, J. (2000). Tillage erosion on slopes with soil conservation structures in the Ethiopian highlands. Soil Tillage Res. 57, 115-127. doi: 10.1016/S0167-1987(00)00138-0

Osman, M., and Sauerborn, P. (2001). Soil and Water Conservation in Ethiopia. J. Soils Sediments 1, 117-123. doi: 10.1007/BF02987717

Pikul, J. L., and Aase, J. K. (1998). Fall contour ripping increases water infiltration into frozen soil. Soil Sci. Soc. Am. J. 62, 1017-1024. doi: 10.2136/sssaj1998.03615995006200040024x

Saxton, K. E., McCool, D. K., and Papendick, R. I. (1981). Slot mulch for runoff and erosion control. J. Soil Water Conserv. 36, 44-47.

Schillinger, W. F., and Wilkins, D. E. (1997). Deep ripping fall-planted wheat after fallow to improve infiltration and reduce erosion. J. Soil Water Conserv. 52, 198-202.

Schumm, S. A., Harvey, M. D., and Watson, C. C. (1984). Incised Channels: Morphology, Dynamics, and Control. Littleton, CO: Water Resources Publications.

Steenhuis, T. S., Hrncir, M., Poteau, D. A., Luna, E. J. R., Tilahun, S. A., Caballero, L. A. et al. (2013). Saturated excess runoff pedotransfer function for vegetated watersheds. Vadose Zone J. 12, 1-10. doi: 10.2136/vzj2013.03.0060

Steenhuis, T. S., and Tilahun, S. A. (2014). "Changes in climate and landscape in the Blue Nile Basin: what it means downstream," in Water Scarcity, Security and Democracy: A Mediterranean Mosaic. Global Water Partnership, eds F. De Chatel, G. Holst Warhaft, and T. S. Steenhuis (Ithaca, NY: Mediterranean and Cornell University Atkinson Center for Sustainable Future), 144-151.

Steenhuis, T. S., Tilahun, S. A., Tesamma, Z. K., Tebebu, T. Y., Mogus, M., Zimale, F. A., et al. (2014). "Soil erosion and discharge in the Blue Nile Basin: trends and challenges," in Nile River Basin Ecohydrological Challenges, Climate Change and Hydropolytics, eds A. M. Melesse, W. Abtew, and S. G. Setegn (Springer), 133-148. doi: 10.1007/978-3-319-02720-3_8

Tamene, L., and Vlek, P. L. G. (2008). "Soil erosion studies in Northern Ethiopia," in Land Use and Soil Resources, eds A. K. Braimoh and P. L. G. Vlek (Springer Science 7 Business Media B.V. Dordrecht), 73-100.

Taye, G., Poesen, J., van Wesemael, B., Vanmaercke, M., Teka, D., Deckers, J., et al. (2013). Effects of land use, slope gradient, and soil and water conservation structures on runoff and soil loss in semi-arid Northern Ethiopia. Phys. Geogr. 34, 236-259. doi: 10.1080/02723646.2013.832098

Tebebu, T. Y. (2009). Assessment of Hydrological Controls on Gully Formation Near Lake Tana, Northern Highlands of Ethiopia. Master's thesis. Cornell University, Ithaca, NY.

Tebebu, T. Y., Abiy, A. Z., Zegeye, A. D., Dahlke, H. E., Easton, Z. M., Tilahun, S. A., et al., (2010). Surface and subsurface flow effect on permanent gully formation and upland erosion near Lake Tana in the northern highlands of Ethiopia. Hydrol. Earth Syst. Sci. 14, 2207-2217. doi: 10.5194/hess-14-22072010

Tebebu, T. Y., Bayabil, H. K., Dagnew, D. C., Guzman, C. D., Zegeye, A. D., Gessess, A. A., et al., (2014). "Spatial and temporal variability of hardpan soils in the Ethiopian highlands," in 2nd International Conference on the Advancements of Science and Technology, eds B. Bantyirga, M. Mehari, V. S. Rao, B. L. Manocha, K. K. Singh, S. Geremew, and E. Tadesse (Bahir Dar: Bahir Dar University Institute of Technology), 154-163.

Tebebu, T. Y., Bayabil, H. K., Guzman, C. D., Gessess, A. A., Tilahun, S. A., and Steenhuis, T. S. (2015). "Assessment of hardpan formation on degraded soils in the humid Ethiopian highlands," in Seventh Annual BEE Symposium (Ithaca, NY: Cornell University), 1-21.

Temesgen, M., Hoogmoed, W., Rockstrom, J., and Savenije, H. (2009). Conservation tillage implements and systems for smallholder farmers in semi-arid Ethiopia. Soil Tillage Res. 104, 185-191. doi: 10.1016/j.still.2008. 10.026

Temesgen, M., Uhlenbrook, S., Simane, B., Van Der Zaag, P., Mohamed, Y., Wenninger, J., et al. (2012). Impacts of conservation tillage on the hydrological and agronomic performance of Fanya juus in the upper Blue Nile (Abbay) river basin. Hydrol. Earth Syst. Sci. 16, 4725-4735. doi: 10.5194/hess-16-47 25-2012

Tesemma, Z. K., Mohamed, Y. A., and Steenhuis, T. S. (2010). Trends in rainfall and runoff in the Blue Nile Basin: 1964-2003. Hydrol. Process. 24, 3747-3758. doi: $10.1002 /$ hyp.7893

Tiffen, M., Mortimore, M., and Gichuki, F. (1994). More People, Less Erosion. Environmemtal Recovery in Kenya. London: ACTS Press in association with the Overseas Development Institute.

Tilahun, S. A. (2012). Observations and Modeling of Erosion from Spatially and Temporally Distributed Sources in the (semi) Humid Ethiopian highlands. $\mathrm{PhD}$ Dissertation. Cornell University, Ithaca, NY.

Tilahun, S. A., Guzman, C. D., Zegeye, A. D., Ayana, E. K., Collick, A. S., Yitaferu, B., et al. (2015). "Spatial and temporal patterns of soil erosion in the semihumid Ethiopian highlands: a case study of Debre Mawi Watershed," in Nile River Basin Ecohydrological Challenges, Climate Change and Hydropolytics, eds A. M. Melesse, W. Abtew, and S. G. Setegn (Springer), 149-163.

Tilahun, S., Guzman, C., Zegeye, A., Engda, T., Collick, A., Rimmer, A., et al. (2013a). An efficient semi-distributed hillslope erosion model for the subhumid Ethiopian Highlands. Hydrol. Earth Syst. Sci. 17, 1051-1063. doi: 10.5194/hess17-1051-2013

Tilahun, S., Mukundan, R., Demisse, B., Engda, T., Guzman, C., Tarakegn, B., et al. (2013b). A saturation excess erosion model. Trans. ASABE 56, 681-695. doi: $10.13031 / 2013.42675$

Wickel, A. J., Van De Giesen, N. C., and Sá, T. D. A. (2008). Stormflow generation in two headwater catchments in eastern Amazonia, Brazil. Hydrol. Process. 22 3285-3293. doi: 10.1002/hyp.6917

Williams, J. D., Wuest, S. B., Schillinger, W. F., and Gollany, H. T. (2006). Rotary subsoiling newly planted winter wheat fields to improve infiltration in frozen soil. Soil Tillage Res. 86, 141-151. doi: 10.1016/j.still.2005.02.019

Yesuf, H. M., Assen, M., Alamirew, T., and Melesse, A. M. (2015). Modeling of sediment yield in Maybar gauged watershed using SWAT, northeast Ethiopia. Catena 127, 191-205. doi: 10.1016/j.catena.2014.12.032

Zegeye, A. D., Damtew, S., Tilahun, A. S., Langendoen, E., Dagnew, D., Guzman, C., et al. (2014). "Gully development processes in the Ethiopian Highlands," in 
2nd International Conference on the Advancements of Science and Technology, eds B. Bantyirga, M. Mehari, V. S. Rao, B. L. Manocha, K. K. Singh, S. Geremew, and E. Tadesse (Bahir Dar: Bahir Dar Institute of Technology), 220-229.

Zegeye, A. D., Steenhuis, T. S., Blake, R. W., Kidnau, S., Collick, A. S., and Dadgari, F. (2010). Assessment of soil erosion processes and farmer perception of land conservation in Debre Mewi watershed near Lake Tana, Ethiopia. Ecohydrol. Hydrobiol. 10, 297-306. doi: 10.2478/v10104-011-0013-8

Ziegler, A. D., and Giambelluca, T. W. (1998). Influence of revegetation efforts on hydrologic response and erosion Kaho'olawe Island, Hawai'i. Land Degrad. Dev. 9, 189-206.
Conflict of Interest Statement: The authors declare that the research was conducted in the absence of any commercial or financial relationships that could be construed as a potential conflict of interest.

Copyright @ 2015 Tebebu, Steenhuis, Dagnew, Guzman, Bayabil, Zegeye, Collick, Langan, MacAlister, Langendoen, Yitaferu and Tilahun. This is an open-access article distributed under the terms of the Creative Commons Attribution License (CC $B Y)$. The use, distribution or reproduction in other forums is permitted, provided the original author(s) or licensor are credited and that the original publication in this journal is cited, in accordance with accepted academic practice. No use, distribution or reproduction is permitted which does not comply with these terms. 